\title{
INFLUENCE OF ACQUAINTANCESHIP WITH A MASS EVENT RULES AND REGULATIONS ON THE PERCEPTION OF THE SELECTED ASPECTS OF SAFETY BY PARTICIPANTS
}

\begin{abstract}
Each and every mass event is an enormous logistics undertaking. The principal task of the organizers of a mass event is to make sure that those who participate in it are safe. Ensuring safety during a mass event consists in, among others, organizing the services ensuring the safety of an event venue. The principal objective of this dissertation was to study the mass event participants' satisfaction with the selected aspects of safety, which included: the actions of the security staff members, the work of the information services, and also medical security. In this dissertation, it is as well the results of research concerning acquaintanceship with the rules and regulations of an event, and also the influence exerted by it upon the perception of the above-described aspects of safety by participants in an event. The research was conducted in February, 2016, on the group of 2,300 individuals, who had participated in XXII Rzeszow Juwenalia, the largest student festival organized in the South-East of Poland. Conducting a survey amongst participants in XXII Rzeszow Juwenalia made it possible to achieve the described objectives, and also to obtain plenty of information concerning that event. For the analysis of data, the STATISTICA program was used. In order to determine the correlation between qualitative traits and the quantitative ones, the ANOVA Kruskal-Wallis test by ranks was used.
\end{abstract}

Keywords: mass events, safety, quality of services.

\section{INTRODUCTION}

Organizing, and also ensuring the security of, a mass event, is an enormous challenge to all the services and individuals taking part in preparations for it. This state of the matters is exerted influence upon not only by ever-stricter legal provisions, but, as well, by the constantly growing needs and requirements of participants in an event ${ }^{3}$. The organizers of mass events should remember about the fact that the greater number of participants,

\footnotetext{
${ }^{1}$ Joanna Woźniak, M. of Eng., Department of Management Systems and Logistics, Rzeszow University of Technology, al. Powstańców Warszawy 8, 35-959 Rzeszów, tel. (17) 86510 73; e-mail address: j.wozniak@prz.edu.pl.

${ }^{2}$ Karol Fill, M. of Eng., coordinator of Rzeszow Juwenalia in the years: 2015-2016, Brend Group, ul. Sportowa 4/29, 35-111 Rzeszów; e-mail address: fill.karol@gmail.com.

${ }^{3}$ D. Zimon, An Attitude of Subcarpathian's Residents to Sustainable Solutions for Urban Transport, International Letters of Natural Sciences, 50/2016, p. 41-56.
} 
the more varied their expectations will be $\mathrm{b}^{4}$. Of course, a lot depends on the kind of an event as well. The spectators at a football match will have needs different to those of concert audiences, or those taking part in religious assemblies. Without doubt, however, those who make a decision to take part in a mass event will be paying attention to: the character and programme of an event, next, to prices, and also the quality of products, as well as to appropriate safety which an organizer can guarantee them . During the analysis of customer satisfaction, attention needs to be paid to the fact that the quality of services is included into subjective categories ${ }^{5}$. What one individual may assess very positively, the other one will as irrelevant, or even perceive negatively.

Participants in a mass event are not only the most numerous, but, as well, the most important element of it. Their behaviour may contribute, to a great degree, to the occurrence of dangerous situations. The literature states that sociology, and also crowd psychology, are a domain which is very difficult to research, and that due to the unpredictability, and also spontaneity, of the behaviour of individuals in the crowd $\mathrm{d}^{6}$. An 'organized' crowd (or a 'psychological' one) consists in the partial loss of awareness, and also their individual traits, by its members. While a crowd is formed, there occurs the process referred to as homogenization ${ }^{7}$. In practice, it means that particular individuals in the crowd adopt the same mood, way of thinking, and also reacting. The specific character of the crowd consists in the fact that, at a certain moment, those it is composed of start to feel anonymous, which, consequently, provides them with the feeling of safety. This state may cause the loss of control over their own actions, and, consequently, increase the impulsiveness and pathological character of behaviour ${ }^{8}$. A major feature of crowd is a substantial potential in terms of actions it could take. Particular individuals are, inadvertently, manipulated by crowd, and frequently forced to engage in actions which would not otherwise be attempt$\mathrm{ed}^{9}$. For that reason as well, each and every mass event involves the risk of the occurrence of an increased number of injuries at the same place and at the same time. Therefore, providing security of a mass event by means of, among others, the safety/protection personnel, the information services, or the medical security, is so important. It is as well significant that participants are acquainted with the rules and regulations of an event, the rules and regulations of a facility (a venue), and also with the generally-applicable provisions of law. Participants' being unaware of law in force frequently increases the risk of dangerous situations, and also results in decreased satisfaction of all those involved in an event.

\footnotetext{
${ }^{4}$ J. Woźniak, Preferred methods of acquiring information by mass event participants [in:] International Scientific Conference of Business Economics Management and Marketing 2017. Proceedings of International Scientific Conference of Business Economics Management and Marketing 2017, Brno: Masaryk University, 2017, p. 308-315.

${ }_{5}^{5}$ R. Wolniak, B. Skotnicka, Metody i narzędzia zarządzania jakością. Teoria i praktyka, Gliwice 2011, p. 170.

${ }^{6}$ J. Piwiński, Modelowanie zbiorowych zachowań ludzkich jako narzędzie wspomagajace zarzqdzanie kryzysowe, Pomiary Automatyka Robotyka, 2/2010.

${ }^{7}$ M. Zajdel, Komputerowe modelowanie zachowań zbiorowości ludzkich w stanach paniki, doctoral dissertation, Akademia Górniczo- Hutnicza im. Stanisława Staszica, Kraków 2013, p. 24.

8 E. Aronson et al, Psychologia społeczna, Poznań 1997, p. 366.

9 D. Markowski, Ttum jako podmiot zachowań zbiorowych [in:] Bezpieczeństwo imprez masowych; joint publication, eds. E. Ura and S. Pieprzny, Rzeszów 2012, p. 204.
} 


\section{OBJECTIVE OF THIS DISSERTATION AND THE METHODOLOGY OF RESEARCH}

The principal objective of this dissertation was to determine the level of mass event participants' satisfaction with the selected aspects of safety, which included:

- actions of the safety/protection personnel,

- work of the information services,

- medical security.

In this dissertation, an auxiliary objective, which consisted in determining the level of acquaintanceship of participants with the rules and regulations of an event, was taken under consideration as well.

In the publication, it was also attempted to verify the following research hypotheses:

- it is assumed that acquaintanceship with the rules and regulations of an event does not exert influence upon the assessment of the actions of the safety/protection personnel upon entering an event venue,

- it is assumed that acquaintanceship with the rules and regulations of an event does not exert influence upon the assessment of the work of the information services while an event is in progress,

- it is assumed that acquaintanceship with the rules and regulations of an event does not exert influence upon the assessment of medical security while an event is in progress.

In the pursuit of the objectives which were adopted, a survey questionnaire made available with the application of the CAWI (Computer-Assisted Web Interview) method was used as a research tool. The questions concerning the assessment of actions of particular services ensuring the security of an event venue were drawn up upon the basis of the five-degree Likert scale, on which ' 1 ' referred to a very low assessment, whereas ' 5 ' a very good one. While assessing the level of acquaintanceship with the rules and regulations, a respondent was using a four-degree scale, on which ' 1 ' referred to not being acquainted with the rules and regulations in question; in turn, ' 4 ' referred to a profound acquaintanceship with the rules and regulations. For the purpose of the analysis, the STATISTICA program was taken advantage of. In the statistical analysis, first and foremost, the cardinality tables, which presented both the numerical collation and the percent one of particular answers, were used. Moreover, the arithmetical means, standard deviations, and also the coefficient of variation, were calculated. In order to verify the hypotheses and determine the correlations between qualitative traits and the quantitative ones, the ANOVA Kruskal-Wallis test by ranks was used. All the processed results were presented in a graphical form.

The research was conducted in February, 2016, on the group of 2,300 individuals, who had participated in XXII Rzeszow Juwenalia, the largest student festival organized in the South-East of Poland. Rzeszow Juwenalia is the perfect instance of a mass event. Several days of artistic and entertainment events, tens of people working in the organizational headquarters, thousands individuals taking part in the event, show the scale and rank of this event ${ }^{10}$. What matters as well is the fact that the community of Rzeszow is young,

${ }^{10} \mathrm{~J}$. Woźniak, Assessment of satisfaction and loyalty of mass event participants as exemplified by XXIII Rzeszow Juwenalia [in:] Business and non-profit organizations facing increased compe- 
which results from the highest in Europe proportion of the number of students to the population ${ }^{11}$. This fact exerts a very strong influence upon the success of the event, and also stimulates the organizers to take actions connected with continuous improvement of their project.

In accordance with the opinion of the authors, the results of research may find practical application, and will certainly be a valuable material for the future organizers of Rzeszow Juwenalia.

\section{DETERMINING ACQUAINTANCESHIP WITH THE RULES AND REGULATIONS OF THE EVENT BY PARTICIPANTS IN XXII RZESZOW JUWENALIA}

In accordance with Polish law ${ }^{12}$, the terms and conditions of a facility (a venue) of an event determines the following issues:

- rules of admission (including, as well, those related to minors),

- rules of behaviour for individuals on a facility or on a venue of an event (for instance, ban on entering with dangerous items, and the consumption of alcohol),

- rules and regulations of using a facility (a venue), and also devices on the facility (a venue) of an event,

- determining the restricted-access areas.

The organizers of a mass event should make the rules and regulations available in such a way that each of the participants in an event, yet prior to its commencement, could make themselves acquainted with the provisions in question, and, thanks to that, be aware of the rights which they possess and incumbent obligations ${ }^{13}$. The audience's acquaintanceship with the rules and regulations currently in force during an event makes the work of the services ensuring the security of an event venue a great deal less difficult, and also reduces the risk of dangerous situations.

The rules and regulations of XXII Rzeszow Juwenalia are available on the premises of the Organizational Committee of Rzeszow Juwenalia, and also on the official webpage of the event. The rules and regulations in question came into force immediately after announcing them, and had remained in force until the organizer declared the event to be closed $^{14}$.

Chart 1 presents the results of the survey concerning acquaintanceship with the rules and regulations in the case of those participating in XXII Rzeszow Juwenalia. 10\% of the respondents (225) declared that they certainly had made themselves acquainted with the rules and regulations in question, whereas $53 \%$ of them $(1,228)$ stated they knew them fairly well. In turn, $29 \%$ of the respondents (678) stated that their acquaintanceship with

tition and growing customers' Demands: Foundation "Cognitione", (eds.) A. Ujwary-Gil, A. Nalepka, Nowy Targ and WSB-NLU, Vol. 16, Nowy Sącz 2017, p. 455-465.

11 Eurostat regional yearbook 2012, Focus on European cities, http://ec.europa.eu/eurostat/ documents/3217494/5735109/KS-HA-12-001-12-EN.PDF/7fe23280-0753-4879-93bd-4b5878fae 0b4? version=1.0 (accessed: 21.12 .2015$)$.

12 Act on Mass Event Security of $20^{\text {th }}$ March, 2009 (Journal of Laws of 2009, issue 62, item 504).

${ }^{13}$ Raport z kontroli wzorców umów stosowanych przez organizatorów imprez masowych, Office of Competition and Consumer Protection, Warszawa 2008, p. 11.

${ }^{14}$ Regulamin imprezy - Rzeszowskie Juwenalia, www.rzeszowskiejuwenalia.pl (accessed: 01.09.2016). 
the rules and regulations in question as poor, and 7\% of them (169) said that they certainly knew them not.

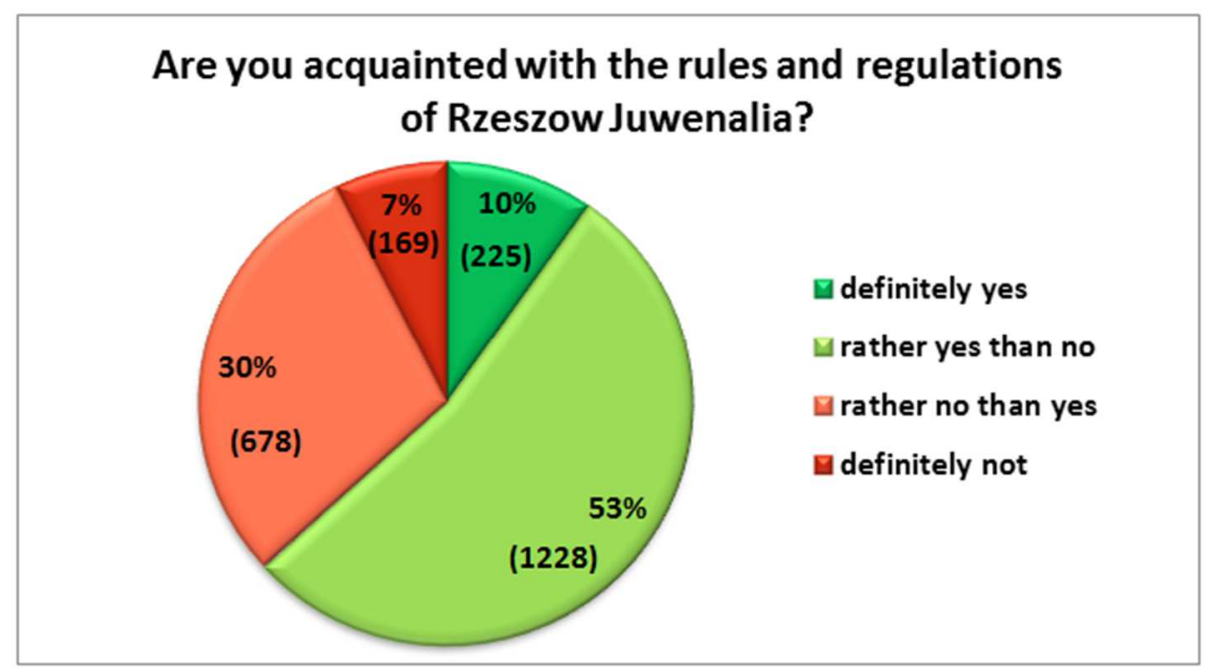

Chart 1. Acquaintanceship with the rules and regulations of an event in the case of participants in XXII Rzeszow Juwenalia

Source: Own elaboration upon the basis of research.

\section{ASSESSMENT OF THE ACTIONS OF THE SAFETY/PROTECTION PERSONNEL}

A significant criterion which exerts influence upon the quality of the organization of mass events and the satisfaction of participants in them is the behaviour of the safety/protection personnel. The rules and regulations of Rzeszow Juwenalia clearly determine the scope of actions of the security staff members of agencies protecting individuals and property, which, in principle, consist in ${ }^{15}$ :

- determining whether particular individuals are entitled to stay on an event venue,

- checking the identity documents of particular individuals in order to determine their identity,

- inspecting the contents of luggage and clothing (if it is suspected that someone is bringing dangerous items, or is carrying alcoholic beverages or soft drinks)

- issuing instructions in the scope of maintaining order, and also requesting individual not permitted to stay on an event venue, or disturbing peace and order, to leave the venue,

- using physical strength in the form of incapacitating holds and similar techniques of defence if there has arisen a danger to the entrusted property, or to defend against an attack,

- apprehending individuals causing a danger to health or life of other participants in order to hand them over to the police immediately.

\footnotetext{
15 Ibidem.
} 
While analysing Chart 2, and also Table 1, it is possible to arrive at the conclusion that the actions taken by the security agency personnel within the event venue entrance zones were assessed as, on average, satisfactory. 329 of the respondents (14\%) are of the opinion that the actions of the security personnel do not meet their expectations. 626 of the respondents $(27 \%)$ declare average satisfaction with their work, in turn, 1,345 of the studied individuals $(59 \%)$ declared to be satisfied, or even very satisfied, with their actions. Paying attention to the value of standard deviation (1.05) is recommendable as well, and so is paying attention to the value of the coefficient of variation $(29.33 \%)$. The received values of those indices prove significant differences of opinions between the respondents, which exert influence, in turn, upon the final results of research.

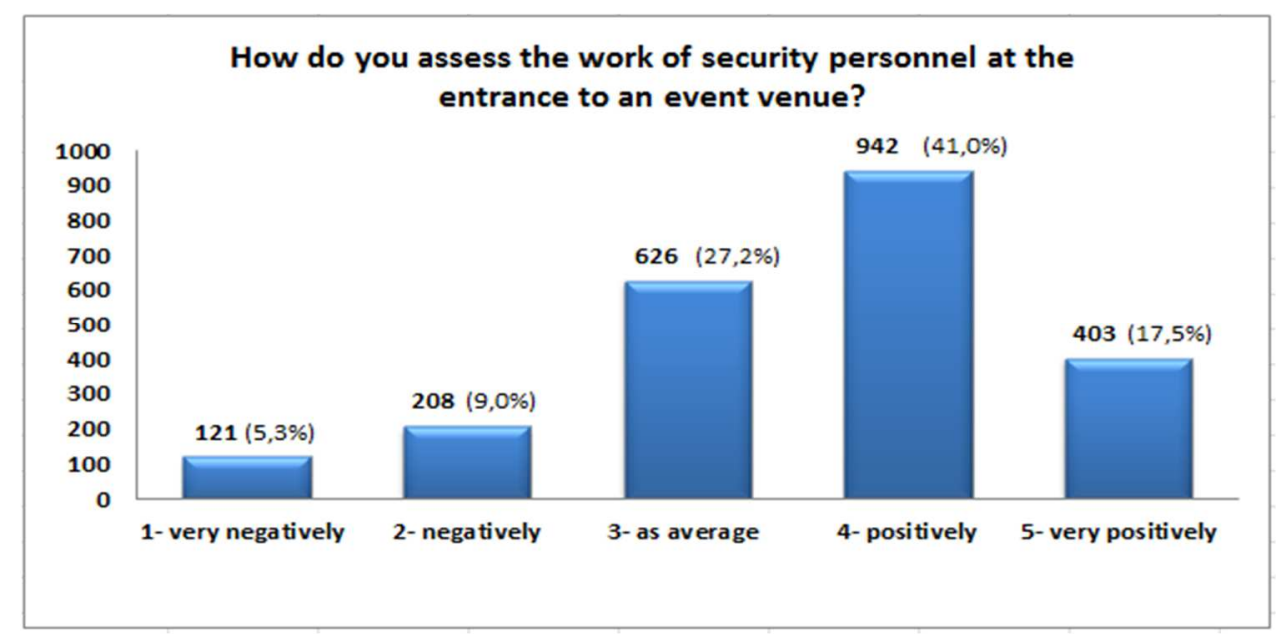

Chart 2. Assessment of the work of security personnel at the event venue entrance

Source: Own elaboration upon the basis of research.

Table 1. Assessment of the work of the security staff members in the entrance zone - the results obtained with the use of selected statistical measurement tools

\begin{tabular}{|c|c|c|}
\hline \multicolumn{3}{|c|}{ ASSESSMENT OF THE ACTIONS OF THE SAFETY/PROTECTION PERSONNEL } \\
IN THE ENTRANCE ZONE
\end{tabular}

Source: Own elaboration upon the basis of research.

In the further part of the research, it was resolved to check whether acquaintanceship with the rules and regulations of an event in the case of participants in it exerts influence upon the assessment of the actions of the security staff members in the entrance zone. For that purpose, the ANOVA Kruskal-Wallis test by ranks was used. 
The described results having the $p$-value, and also the assumed significance level $\alpha=0.05$, making it possible to reject the null hypothesis. Therefore, the value of the ANOVA Kruskal-Wallis test by ranks H $(3, \mathrm{~N}=2300)=20.80611$, and also $\mathrm{p}=0.0001$, making it possible to ascertain that it is most likely that there is a correlation between acquaintanceship with the rules and regulations of an event in the case of the participants in XXII Rzeszow Juwenalia and their assessment of the actions of the security staff members in the entrance zone.

The data contained in Chart 3 make it justifiable to claim that the better acquaintanceship with the rules and regulations of an event is, the greater satisfaction with the actions of security personnel in the case of the participants in XXII Rzeszow Juwenalia. The individuals who defined their acquaintanceship with the rules and regulations as very good, assessed the actions of security personnel as being at the level of 3.73. In turn, the individuals who declared they certainly did not know the rules and regulations of an event assessed the work of security personnel as being at the average level (3.31).

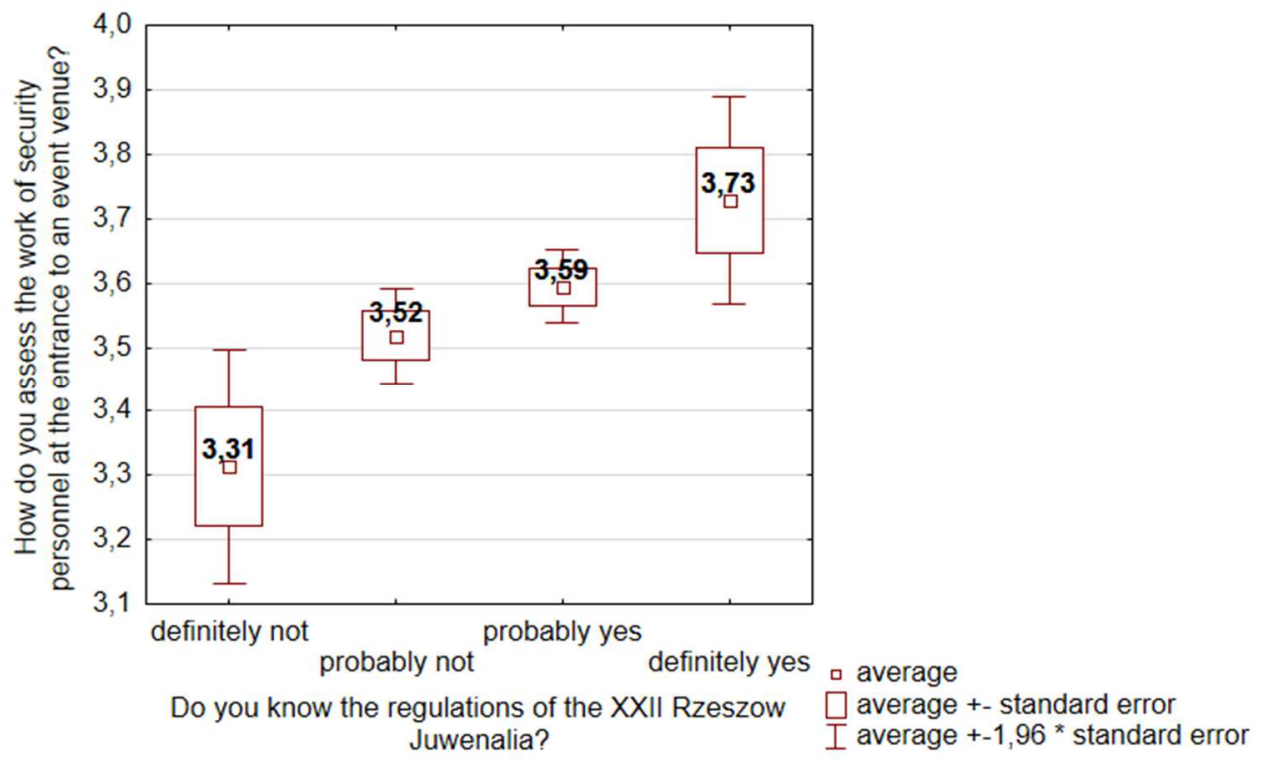

Chart 3. Analysis of the correlations between acquaintanceship with rules and regulations in the case of the participants in an event and the assessment of the work of security personnel in the entrance zone

Source: Own elaboration upon the basis of research.

\section{ASSESSMENT OF THE WORK OF THE INFORMATION SERVICES}

Another, and undeniably one of the most important group of staff who are in direct contact with end service recipients are the information service members. It is worth pointing out that the information service members contact the participants in an event most frequently, and their outside appearance and behaviour shows if the organizer is professional. They should evoke trust and make others feel safe, be very patient, open, and also 
communicative ${ }^{16}$. Moreover, the speed of reaction, which is manifested, for instance, in willingness to help and dedication to assistance, or in reacting to the requests and complaints of the participants in an event, is important.

The information service members during Rzeszow Juwenalia are volunteers, being, principally, students. Before the commencement of the event, they undergo training with the coordinators and organizers of an event, the officers from the City Police Headquarters, medical services, and also safety manager. The principal task of the information service members is to contribute to the safety of the participants in an event, in particular, by means of informing them about the adopted organizational solutions, such as:

- programme of the event,

- map of the event venue (showing, for instance, particular sectors and evacuation routes),

- the rules and regulations of an event,

- managing the crowd.

Chart 4, and also Table 2, make it possible to ascertain that the work of the information services during XXII Rzeszow Juwenalia was satisfactory for the participants. 1,546 of the respondents $(67 \%)$ assess the work of the information services as good or very good. 638 of the respondents $(28 \%)$ are of the opinion that the work of the information services is fairly good, whereas 116 of them (5\%) expressed their dissatisfaction in that aspect. In addition, it was ascertained that the diversity of the respondents' answers concerning the assessment of the work of the information services is not as large as in the case of the assessment of the work of the security staff members in the exit zone. In that latter case, the value of standard deviation amounts to 0.81 , whereas the value of the coefficient of variation to $21.44 \%$.

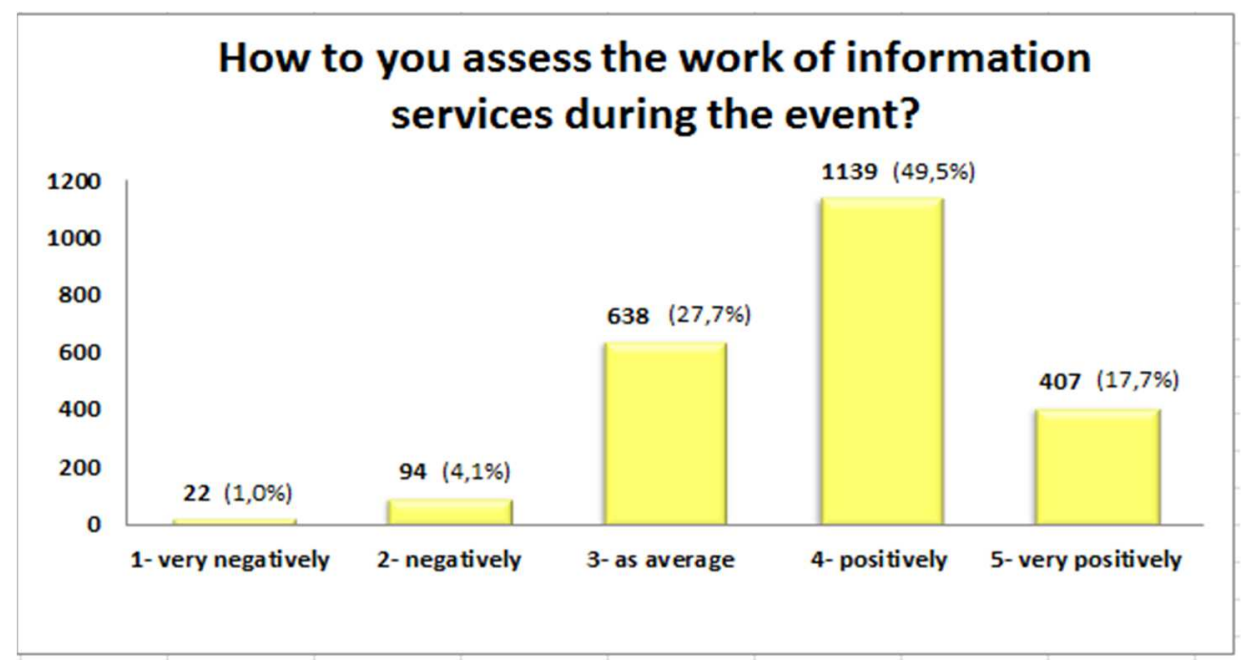

Chart 4. Assessment of the work of the information services

Source: Own elaboration upon the basis of research.

${ }^{16}$ S. Parszowski, A. Kruczyński, Imprezy masowe. Organizacja, bezpieczeństwo, dobre praktyki, Warszawa 2015, p. 70. 
Table 2. Assessment of the work of the information services - results obtained with the use of selected statistical measurement tools

\begin{tabular}{|c|c|c|}
\hline \multicolumn{3}{|c|}{ ASSESSMENT OF THE WORK OF THE INFORMATION SERVICES } \\
\hline AVERAGE & STANDARD DEVIATION & COEFFICIENT OF VARIATION \\
\hline 3.79 & 0.81 & $21.44 \%$ \\
\hline
\end{tabular}

Source: Own elaboration upon the basis of research.

Another studied correlation in the publication was the analysis of links between acquaintanceship with the rules and regulations of an event in the case of participants in it and the assessment of the work of the information services during the event. To research this link, the ANOVA Kruskal-Wallis test by ranks was used again.

The results of the conducted analysis, having the $p$-value, the assumed significance level $\alpha=0.05$, and also the value of the ANOVA Kruskal-Wallis test by ranks H (3, $\mathrm{N}=2300)=78.59044, \mathrm{p}=0.0000$ mean that it is most likely that there exists a correlation between acquaintanceship with the rules and regulations of an event in the case of participants in it and the assessment of the work of the information services during the event.

Analysing the collected data contained in Chart 5, it is possible to ascertain that the majority of individuals acquainted with the rules and regulations of Rzeszow Juwenalia assessed the work of the information services during the event more positively. Individuals who definitely did not know the rules and regulations of the event assessed the actions of the information services as being at the level of 3.42, whereas the respondents declaring a profound acquaintanceship with the rules and regulations assessed the work of the discussed services as being at the level of 4.04 .

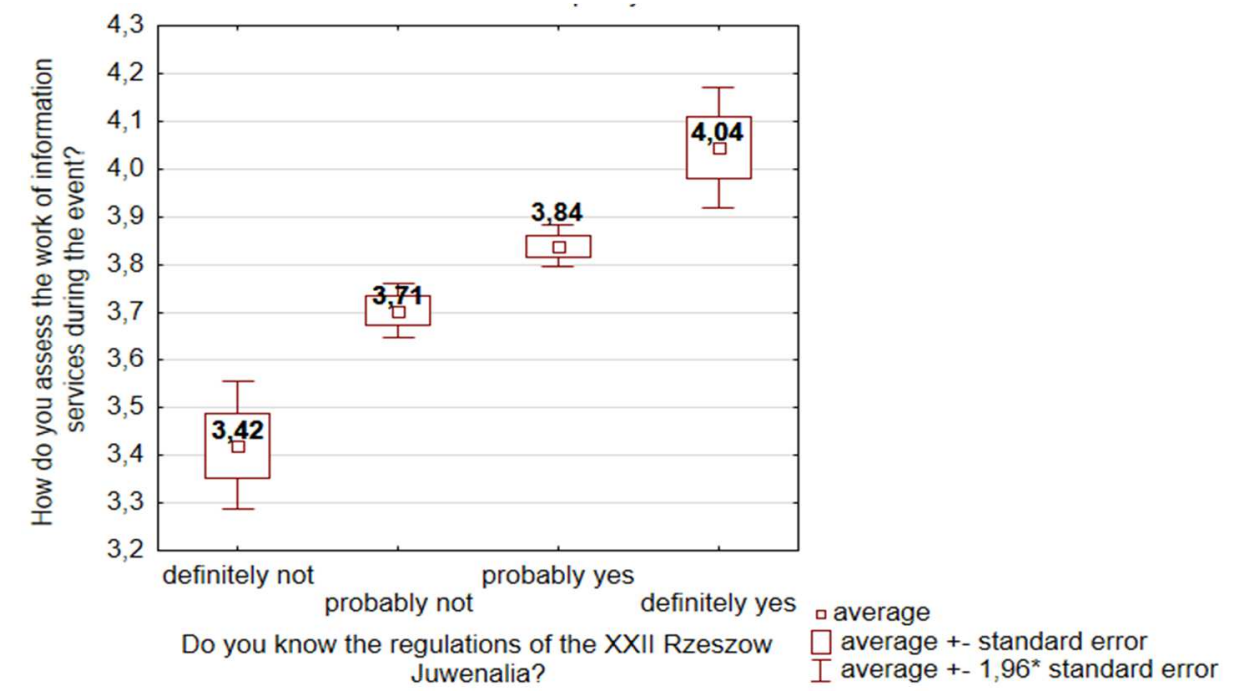

Chart 5. Analysis of the correlation between acquaintanceship with rules and regulations in the case of participants in an event and the assessment of the work of the information services

Source: Own elaboration upon the basis of research. 


\section{ASSESSMENT OF MEDICAL SECURITY}

Medical security is another condition to be fulfilled for the sake of the health and life of participants in an event. As it is claimed by A. Trzos, the way in which medical security is prepared and provided during a mass event is dependent upon the kind of an event and upon the factors which exert influence upon the level of safety. Each and every mass event has a different index of medical interventions, and also transportation to hospitals. Ensuring the appropriate number of location of medical care staff on the venue makes it possible to attempt to intervene rapidly when the danger to participants' life arises ${ }^{17}$.

Regardless of the kind of a mass event, the actions of the medical services during the event are connected with providing at least ${ }^{18}$ :

- a stationary medical point (with no fewer than two individuals, including: a doctor having the right to practice, and also at least three years of experience in providing medical services, and also a medical rescue worker or registered nurse),

- an ambulance on duty (a mobile basic medical rescue team - not including a doctor, whereas a mobile specialist medical rescue team must include a doctor),

- foot patrols the task of which is to move amongst the participants in an event. A medical rescue patrol should be composed of no fewer than two individuals who are qualified to provide first aid (at least), and also have required equipment.

As it is presented in Chart 6, and also in Table 3, the quality of medical security during XXII Rzeszow Juwenalia was defined as good. As it is shown by research, in the opinion

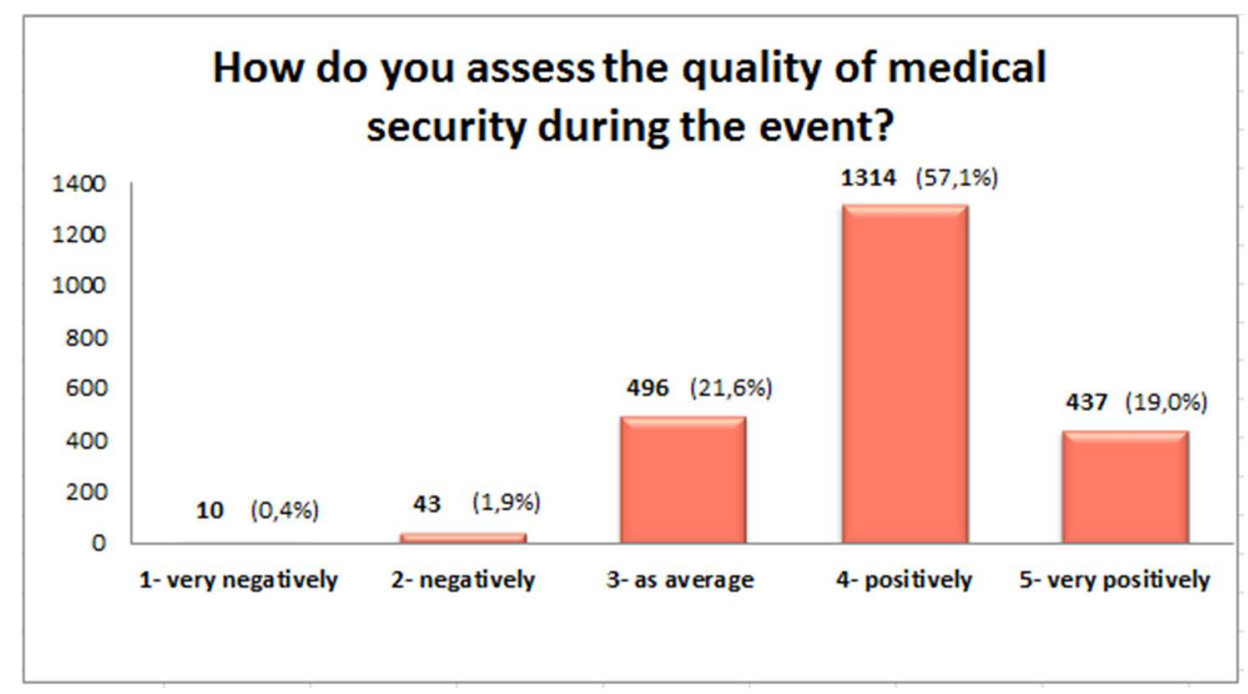

Chart 6. Assessments of medical security

Source: Own elaboration upon the basis of research.

17 A. Trzos, Zabezpieczenie medyczne imprez masowych, Syllabus from the Conference: Bezpieczeństwo na Uczelniach Wyższych. Organizacja imprez masowych, Instytut PWN, Centrum Konferencyjne Zielna, Warszawa, 27.06.2016.

18 Ordinance of the Minister of Health of $6^{\text {th }}$ February, 2012, on Minimum Requirements Concerning Medical Security of a Mass Event (Journal of Laws of $17^{\text {th }}$ February, 2012, item 181). 
Table 3. Assessments of medical security - results for the selected statistical measurement tools

\begin{tabular}{|c|c|c|}
\hline \multicolumn{3}{|c|}{ ASSESSMENTS OF MEDICAL SECURITY } \\
\hline AVERAGE & STANDARD DEVIATION & COEFFICIENT OF VARIATION \\
\hline 3.92 & 0.72 & $18.27 \%$ \\
\hline
\end{tabular}

Source: Own elaboration upon the basis of research.

of 1,751 of the studied $(76 \%)$ it met their requirements well or very well, in turn, 496 $(22 \%)$ of the respondents state that the quality was average. 53 of the respondents $(2 \%)$ expressed their dissatisfaction in this aspect. Taking under consideration standard deviation, and also the coefficient of variation, and comparing them with the research presented in subsections 3 and 4, it is revealed that in this case the indices in question are at the lowest level, and amount, respectively, to: 0.72 and $18.27 \%$.

The last correlation which was presented in this dissertation concerned the link between acquaintanceship with the rules and regulations of an event in the case of participants in XXII Rzeszow Juwenalia and the assessment of medical facilities during the event. For that purpose, similarly to what was the case during the previous analyses, the ANOVA Kruskal-Wallis test by ranks was used.

For the level of $p$-value, the adopted significance level $\alpha=0.05$, and also the value of the ANOVA Kruskal-Wallis test by ranks H $(3 . \mathrm{N}=2300)=95.46848, \mathrm{p}=0.0000$, it was most likely that there existed a correlation between acquaintanceship with the rules and regulations of an event in the case of participants in it and the assessment of medical security during the event.

Chart 7 presents the described correlation in a graphical form. Upon its basis, it is possible to arrive at the conclusion that the more profound acquaintanceship with the rules

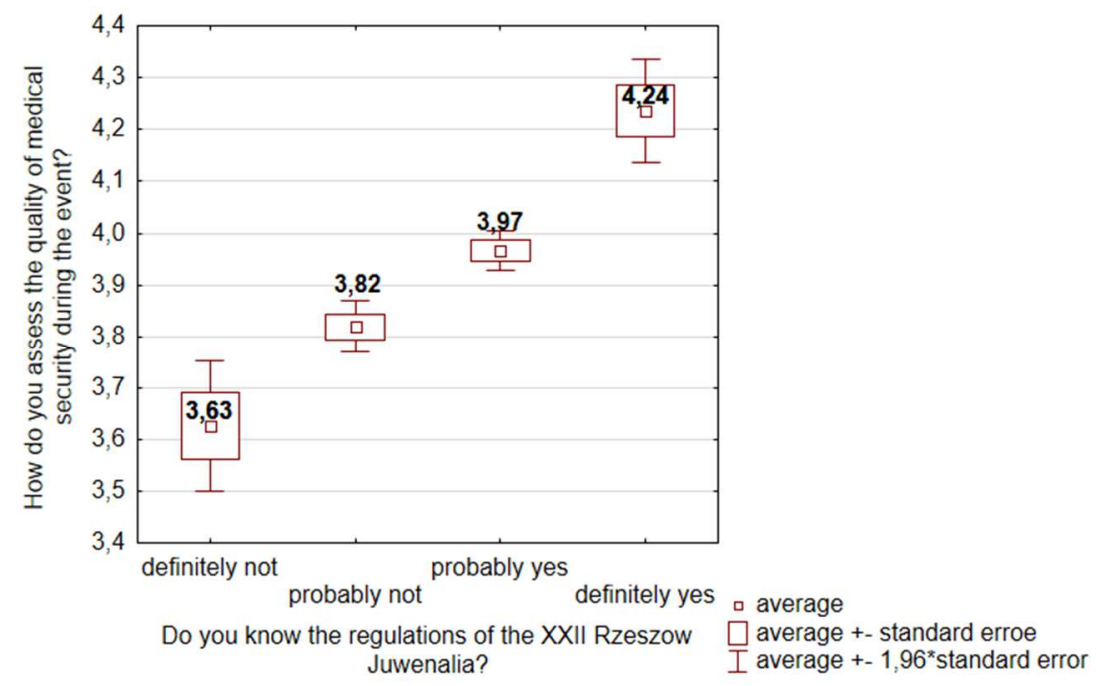

Chart 7. Analysis of correlation between acquaintanceship with rules and regulations in the case of participants in an event and the assessment of medical security

Source: Own elaboration upon the basis of research. 
and regulations of an event, the greater satisfaction of participants with the medical facilities. The individuals who manifested least acquaintanceship with the rules and regulations of the event, assessed the functioning of medical security as being at the level of 3.63, in turn, the respondents declaring a profound acquaintanceship with the rules and regulations in questions assessed the work of the medical services as being at the level of 4.24.

\section{CONCLUSIONS}

The principal objective of this treatise was to measure the satisfaction of the participants in XXII Rzeszow Juwenalia with the selected aspects of safety which included: the actions of the safety/protection personnel, the work of the information services, and also of the medical security. The research gives rise to the conclusion that, in general, the participants in XXII Rzeszow Juwenalia are satisfied with the security level at the event, and the majority of the selected aspects connected with safety were assessed positively (as good).

The process of research made it possible as well to verify the adopted research hypotheses. Upon their basis, the following conclusions were formulated:

- most likely, there exists a correlation between acquaintanceship with the rules and regulations of the event by participants in XXII Rzeszow Juwenalia and their assessment of the actions of the security staff members in the entrance zone. The more profound acquaintanceship with the rules and regulations of an event, the greater the participants' satisfaction with the actions of the security personnel.

- most likely, there exists a correlation between acquaintanceship with the rules and regulations of the event by participants in it and the assessment of the work of the information services during the event. Individuals acquainted with the rules and regulations of Rzeszow Juwenalia assessed, in their majority, the work of the information services better in comparison with individuals, who were not acquainted with the rules and regulations in question.

- most likely, there exists a correlation between acquaintanceship with the rules and regulations of the event by participants in it in an assessment of medical security during the event. The more profound acquaintanceship with the rules and regulations of an event, the greater satisfaction of the participants with the medical facilities.

In recapitulation, one should not forget about the fact that specific mass events make acquaintanceship with the rules and regulations of an event by participants in it is an aspect of extraordinary importance both for organizers, and those involved alike. Lack of awareness of the participants in terms of certain orders and restrictions frequently results in 'the unpleasant ambience' of an event, which results in decreased satisfaction of all the individuals taking part in it. The research proved that $37 \%$ of the respondents are not acquainted with the rules and regulations of XXII Rzeszow Juwenalia. For that reason as well, the organizers of the event should take necessary steps to intensify the promotion of it, and, ipso facto, to persuade potential participants in this event to make themselves profoundly acquainted with the legal provisions currently in force. 


\section{REFERENCES}

[1] Aronson E. et al., Psychologia społeczna, Zysk i S-ka, Poznań 1997.

[2] Eurostat regional yearbook 2012, Focus on European cities, http://ec.europa.eu/ eurostat/documents/3217494/5735109/KS-HA-12-001-12-EN.PDF/7fe23280-07534879-93bd-4b5878fae0b4?version=1.0 (dostęp: 21.12.2015).

[3] Markowski D., Tłum jako podmiot zachowań zbiorowych [in:] Bezpieczeństwo imprez masowych, collective publication, eds. E. Ura and S. Pieprzny, RS Druk, Rzeszów 2012.

[4] Parszowski S., Kruczyński A., Imprezy masowe. Organizacja, bezpieczeństwo, dobre praktyki, Difin, Warszawa 2015.

[5] Piwiński J., Modelowanie zbiorowych zachowań ludzkich jako narzędzie wspomagające zarzadzanie kryzysowe, „Pomiary Automatyka Robotyka” 2010, 14 (2).

[6] Raport z kontroli wzorców umów stosowanych przez organizatorów imprez masowych, Urząd Ochrony Konkurencji i Konsumentów, 2008.

[7] Regulamin imprezy - Rzeszowskie Juwenalia, www.rzeszowskiejuwenalia.pl (accessed: 01.09.2016).

[8] Ordinance of the Minister of Health of $6^{\text {th }}$ February, 2012, on Minimum Requirements Concerning Medical Security of a Mass Event ("Journal of Laws" of $17^{\text {th }}$ February, 2012, item 181).

[9] Trzos A., Zabezpieczenie medyczne imprez masowych, Konspekt z Konferencji: Bezpieczeństw na Uczelniach Wyższych. Organizacja imprez masowych, Instytut PWN, Warszawa, Centrum Konferencyjne Zielna, 27.06.2016.

[10] Act on Mass Event Security of $20^{\text {th }}$ March, 2009 ("Journal of Laws" of 2009, issue 62, item 504).

[11] Wolniak R., Skotnicka B., Metody i narzędzia zarządzania jakościa. Teoria i praktyka, Wydawnictwo Politechniki Śląskiej, Gliwice 2011.

[12] Woźniak J., Assessment of satisfaction and loyalty of mass event participants as exemplified by XXIII Rzeszow Juwenalia [in:] Business and non-profit organizations facing increased competition and growing customers' Demands: Foundation "Cognitione", eds. A. Ujwary-Gil, A. Nalepka, Nowy Targ and WSB-NLU, Vol. 16, Nowy Sącz 2017, p. $455-465$.

[13] Woźniak J., Preferred methods of acquiring information by mass event participants [in:] International Scientific Conference of Business Economics Management and Marketing 2017. Proceedings of International Scientific Conference of Business Economics Management and Marketing 2017, Masaryk University, Brno 2017, p. 308-315

[14] Zajdel M., Komputerowe modelowanie zachowań zbiorowości ludzkich w stanach paniki, rozprawa doktorska, Akademia Górniczo-Hutnicza im. Stanisława Staszica, Kraków 2013.

[15] Zimon D., An Attitude of Subcarpathian's Residents to Sustainable Solutions for Urban Transport, "International Letters of Natural Sciences" 2016, 50, p. 41-56. 


\section{WPEYW ZNAJOMOŚCI REGULAMINU IMPREZY MASOWEJ NA POSTRZEGANIE PRZEZ JEJ UCZESTNIKÓW WYBRANYCH ASPEKTÓW BEZPIECZEŃSTWA}

Każda impreza masowa to ogromne przedsięwzięcie logistyczne. Stworzenie odpowiednich warunków dla wszystkich uczestników wydarzenia (w tym również osób funkcyjnych) nie jest rzeczą łatwą. Powodem tego jest fakt, że wydarzenia te są często niestandardowe, a na ich różnorodność wpływa chociażby charakter samego widowiska, miejsce i czas jego trwania oraz liczba przybyłych uczestników. Organizatorzy imprez masowych stosują wiele działań, które mają na celu przyciągnięcie potencjalnych widzów oraz zapewnienie ich satysfakcji z uczestnictwa w wydarzeniu. Gwarancja najwyższych standardów jakości w każdym obszarze projektu ma więc ogromne znaczenie na powodzenie i sukces realizowanego przedsięwzięcia. Głównym zadaniem organizatorów imprezy masowej jest zapewnienie bezpieczeństwa jej uczestników. Zapewnienie bezpieczeństwa podczas imprezy masowej polega między innymi na organizacji służb zabezpieczających teren imprezy. Głównym celem pracy było zbadanie satysfakcji uczestników imprezy masowej z wybranych aspektów bezpieczeństwa, do których zaliczono: działania pracowników ochrony, pracę służb informacyjnych oraz zabezpieczenie medyczne. W pracy przedstawiono również wyniki badań dotyczące znajomości regulaminu imprezy oraz jego wpływu na postrzeganie przez uczestników imprezy wyżej opisanych aspektów bezpieczeństwa. Badanie przeprowadzono w lutym 2016 roku na grupie 2300 osób, które uczestniczyły w XXII Rzeszowskich Juwenaliach - największym studenckim święcie organizowanym w południowo-wschodniej Polsce. Przeprowadzenie badania ankietowego wśród uczestników XXII Rzeszowskich Juwenaliów pozwoliło na osiągnięcie opisanych celów oraz otrzymanie szeregu informacji dotyczących wydarzenia. Do analizy danych wykorzystano program STATISTICA. W celu określenia zależności między cechami jakościowymi a ilościowymi użyto testu ANOVA rang Kruskala-Wallisa.

Słowa kluczowe: imprezy masowe, bezpieczeństwo, jakość usług.

DOI: $10.7862 /$ rz.2017.mmr.37

Tekst złożono $w$ redakcji: listopad $2016 r$.

Przyjęto do druku: grudzień 2017 r. 